\title{
Implementasi Logika Fuzzy Tsukomoto Dalam Menentukan Harga Coating Mobil Di Prime Coating Medan
}

\author{
Darmawaitus Giawa $^{\mathrm{a} 1}$, Murni Marbun ${ }^{\mathrm{a} 2}$ \\ ${ }^{a}$ STMIK Pelita Nusantara Jl. St. Iskandar Muda No. 1 Medan, Indonesia \\ 'darmangiawa34@gmail.com,2dimpleflorence@yahoo.co.id
}

\begin{abstract}
INFORMASI ARTIKEL
Kata Kunci:

Logika Fuzzy

Metode Tsukomoto

Harga Coating Mobil

SPK

Logika

\section{ABSTRAK}

Sampai saat ini masih banyak perusahaan yang mengabaikan metode penetapan harga jasa walaupun harga memegang peraturan yang sangat penting dalam keputusan suatu perusahaan. Dalam menentukan harga coating mobil pelanggan, perusahaan Prime Coating sangat sulit dalam mengambil suatu keputusan untuk menentukan keseimbangan harga antara tipe layer yang digunakan dengan jenis ukuran mobil yang dikerjakan. Penelitian ini bertujuan membuat suatu aplikasi yang dapat digunakan untuk menentukan harga jasa coating mobil yang dikerjakan berdasarkan ukuran mobil dan tipe layer yang digunakan. Metode penetuan harga menerapkan metode logika fuzzy. Terdapat beberapa metode logika fuzzy yang bisa digunakan untuk memprediksi suatu harga. Salah satu metode yang dapat digunakan untuk memprediksi harga jasa coating mobil adalah metode Tsukamoto dimana, setiap rule direpresentasikan kedalam suatu himpunan fuzzy dengan fungsi keanggotaan yang monoton yang disebut dengan fuzzifikasi. Aplikasi dibangun menggunakan bahasa pemograman PHP dan HTML dan Database Mysql. Hasil penelitian menunjukkan bahwa metode Logika Fuzzy Tsukamoto dapat menentukan harga coating mobil berdasarkan jumlah layer dan ukuran mobil. Implementasi sistem untuk harga jasa coating jenis mobil Agya dengan ukuran mobil 14 dan jumlah layer 2 adalah Rp 2.000.000. Aplikasi yang dibangun dapat membantu Prime Coating Medan dalam menentukan harga coating mobil dengan efektif.
\end{abstract}

\section{Keywords:}

Fuzzy Logic

Tsukomoto method

Car Coating Price

SPK

Logica

\section{ABSTRACT}

Until now, there are still many companies that ignore the method of pricing services, even though prices hold very important rules in a company's decisions. In determining the price of a customer's car coating, it is very difficult for Prime Coating companies to make a decision to determine the price balance between the type of coating used and the size of the car being worked on. This study aims to create an application that can be used to determine the price of car coating services based on the size of the car and the type of coating used. The pricing method applies the fuzzy logic method. There are several fuzzy logic methods that can be used to predict prices. One method that can be used to predict the price of car coating services is the Tsukamoto method where each rule is represented in a fuzzy set with a monotonic membership function called fuzzification. This application is built using the PHP and HTML programming languages and the Mysql database. The results showed that the Tsukamoto Fuzzy Logic method can determine the price of car coatings based on the number of layers and the size of the car. The implementation of the Agya car coating service price system with a car size of 14 and the number of layers of 2 is $R p$. 2,000,000. The application that is built can help Prime Coating Medan in determining the price of car coatings effectively.

\section{Pendahuluan}

Istilah Coating Mobil merupakan suatu kegiatan ataupun pekerjaan yang biasa dilakukan oleh perusahaan di bidang otomotif, salah satunya di Premium Nano Coating (Prime Coating), yang merupakan salah satu perusahaan yang terletak di jalan Nibung Raya No 27 Medan Sumatera Utara, yang sekarang ini sedang berkembang pesat dalam hal pekerjaan nano ceramic coating mobil, terutama dalam hal melapisi (coating) bagian cat body luar mobil. Tidak sedikit para pengguna mobil punya gairah dalam hal merawat mobil, bahkan disemua kalangan masyarakat dari desa hingga wilayah perkotaan. 
Semua perusahaan baik yang berusaha dengan tujuan laba maupun yang bertujuan nirlaba akan menghadapi masalah-masalah yang berhubungan dengan penetapan harga atas jasa yang mereka tawarkan [1]. Hal tersebut tidak dapat dipungkiri keberadaannya, meskipun demikian, sampai saat ini masih banyak perusahaan yang mengabaikan masalah penetapan harga jasa walaupun harga memegang peraturan yang sangat penting dalam keputusan suatu perusahaan. Sebagai contoh masalah yang saat ini terjadi di Prime Coating Medan, adalah masalah dalam hal menentukan harga jasa coating mobil yang dikerjakan berdasarkan ukuran mobil dan tipe layer yang digunakan. Untuk menentukan harga coating mobil pelanggan, perusahaan Prime Coating, sangat sulit dalam mengambil suatu keputusan untuk menentukan keseimbangan harga antara tipe layer yang digunakan dengan jenis ukuran mobil yang dikerjakan. Demi menghindari masalah tersebut, maka peneliti tertarik mengangkat penelitian dalam menentukan harga coating mobil dengan menerapkan metode Logika Fuzzy Tsukamoto berdasarkan tipe layer dan jenis ukuran yang dikerjakan.

Salah satu cabang ilmu komputer yang dapat digunakan dalam menentukan harga coating mobil adalah menggunakan metode Logika Fuzzy . Logika Fuzzy adalah metodologi sistem kontrol pemecahan masalah pada sistem, mulai dari sistem yang sederhana sampai sistem yang rumit atau kompleks [2],[3]. Dalam Logika Fuzzy terdapat beberapa metode yang bisa digunakan untuk memprediksi suatu harga. Salah satu metode yang dapat digunakan untuk memprediksi harga jasa coating mobil adalah metode Tsukamoto. Metode ini dipilih karena sifatnya yang fleksibel, dan memiliki toleransi pada data yang ada [4],[5]. Kelebihan dari metode ini yaitu lebih cepat dalam melakukan komputasi, lebih intuitif, diterima oleh banyak pihak, lebih cocok untuk masukan yang diterima dari manusia bukan oleh mesin[6],[7]. Pada metode Tsukamoto, setiap Rule direpresentasikan dengan suatu himpunan Fuzzy dengan fungsi keanggotaan yang monoton disebut dengan fuzzifikasi. Sebagai hasilnya, keluaran hasil dari tiap-tiap aturan berupa nilai tegas ( crisp) berdasarkan $\alpha$-predikat atau nilai minimum dari tiap Rule dan nilai z. Hasil akhirnya diperoleh dengan melakukan defuzzifikasi rata-rata berbobot [8].

Berdasarkan penelitian terdahulu yaitu "Sistem Pakar Diagnosis Penyakit Hati Menggunakan Metode Fuzzy Tsukamoto Berbasis Android" nilai masukan gejala yang menghasilkan keluaran berupa keterangan terdeteksi atau tidaknya suatu penyakit hati, menghasilkan pengujian akurasi dari 64 data uji sebesar 96,87\% [9]. Dari penelitian diatas dapat disimpulkan bahwa penggunaan metode Fuzzy Tsukamoto berhasil diterapkan dengan tingkat akurasi 96,87\% dan sangat mendukung jika digunakan dalam penelitian ini, dengan harapan penelitian ini juga dapat bermanfaat bagi perusahaan Prime Coating Medan atau pihak lainnya dalam menyelesaikan permasalahan penentuan harga.

\section{Metode}

\subsection{Tahapan Penelitian}

1. Pengumpulan Data

Pada tahap ini merupakan aktivitas mencari atau mengumpulkan data untuk memperoleh informasi yang dibutuhkan dalam rangka mencapai tujuan penelitian seperti:

a. Literatur

Pada tahap studi literatur penelitian ini mengumpulkan dasar-dasar toeri dan informasi dari buku dan jurnal yang berkaitan dengan kebutuhan penelitian terkait dengan pokok bahasan masalah. Dalam studi literatur dilakukan mengenai studi kasus yang berkaitan dengan penentuan harga dengan menggunakan fuzzy tsukamoto.

b. Observasi

Obsevasi adalah aktivitas untuk mendapatkan informasi yang jelas dengan cara mengamati secara langsung. Observasi bertujuan mendeskripsikan kegiatan yang terjadi serta pihak-pihak yang terlibat di dalamnya. Dengan observasi peneliti mengumpulkan data mobil yang sudah dikerjakan (masuk/keluar) dalam 1 tahun terakhir.

c. Wawancara

Tujuan dari wawancara adalah untuk memperoleh informasi dan memperluas data yang didapat dari pihakpihak lain seperti pemilik perusahaan Prime Coating Medan, beliau adalah Bapak Hendri, dimana pewawancara memberikan pertanyaan-pertanyaan untuk dijawab oleh pihak yang diwawancarai. Hasil dari wawancara tersebut akan dijadikan acuan untuk proses penelitian lebih lanjut.

\subsection{Metode Tsukomoto}

Pada tahapan ini setelah peneliti mengumpulkan data dan informasi, maka peneliti menerapkan metode Tsukamoto dalam menentukan harga coating mobil di Prime Coating Medan. Proses pengambilan keputusan 
dengan menggunakan metode Fuzzy Tsukamoto dilakukan dengan melalui beberapa tahapan, yaitu penentuan variabel fuzzy, penentuan himpunan fuzzy, fuzzyfikasi, pembentukan aturan fuzzy (fuzzy rule) dalam bentuk IF...THEN, dan proses inferensi dengan menggunakan metode Tsukamoto.

Secara umum terdapat beberapa langkah dalam menyelesaikan permasalahan dengan metode tsukamoto,yaitu sebagai berikut [10]:

1. Menentukan Variabel Fuzzy Variabel fuzzy merupakan variabel yang hendak dibahas dalam suatu sistem fuzzy.

2. Menentukan Himpunan Fuzzy Himpunan fuzzy merupakan suatu grup yang mewakili suatu kondisi atau keadaan tertentu dalam suatu variabel fuzzy

3. Fuzzifikasi

a. Menentukan fungsi keanggotaan setiap himpunan fuzzy pada masing masing variabel fuzzy sesuai dengan representasi yang digunakan

b. Menghitung nilai keanggotaan berdasarkan fungsi keanggotaan yang telah diperoleh

4. Pembentukan aturan fuzzy (fuzzy rule) dalam bentuk IF...THEN...

5. Proses inferensi dengan menggunakan metode Tsukamoto

a. Menghitung nilai $\alpha$-predikat tiap-tiap rule $(\alpha 1, \alpha 2, \alpha 3 \ldots . . ., \alpha$ n) dengan fungsi implikasi MIN. $\alpha$-predikatn $=\min [\mu \mathrm{A}(\mathrm{x}) ; \mu \mathrm{B}(\mathrm{y})]$

b. Menghitung hasil inferensi secara tegas (crips) masing-masing rule ( $\mathrm{z} 1, \mathrm{z} 2, \mathrm{z} 3, \ldots \ldots, \mathrm{zn})$ dari masing-masing nilai $\alpha$-predikat yang telah diketahui

6. Defuzzifikasi dengan menggunakan metode weighted average atau rata rata terbobot.

$$
Z=\frac{\left(\alpha-\text { predikat }_{1} * Z_{1}\right)+\left(\alpha-\text { predikat }_{2} * Z_{2}+\ldots \ldots+\left(\alpha-\text { predikat }_{n} * Z_{n}\right.\right.}{\alpha-\text { predikat }_{1}+\alpha-\text { predikat }_{2} \ldots \ldots+\left(\alpha-\text { predikat }_{n}\right)}
$$

\section{Hasil dan Pembahasan}

Data yang akan diolah untuk mengetahui harga coating mobil dengan penerapan Metode Fuzzy Tsukomoto terdiri dari ukuran mobil berdasarkan ukuran vleg dan jumlah layer. Daftar variable dan domain dapat dilihat pada tabel berikut ini.

Tabel 1. Kriteria dan Variabel Penelitian.

\begin{tabular}{|c|c|c|c|}
\hline & & Jenis Variabel & Domain \\
\hline \multirow{6}{*}{$\begin{array}{c}\text { Variabel } \\
\text { Input }\end{array}$} & \multirow{3}{*}{$\begin{array}{c}\text { Ukuran } \\
\text { Mobil }\end{array}$} & Kecil & $\begin{array}{l}13-17] \\
\end{array}$ \\
\hline & & Sedang & [14-18] \\
\hline & & Besar & [15-20] \\
\hline & \multirow{3}{*}{$\begin{array}{c}\text { Jumlah } \\
\text { Layer }\end{array}$} & Sedikit & [1-3] \\
\hline & & Sedang & {$[2-5]$} \\
\hline & & Banyak & [4-7] \\
\hline \multirow{3}{*}{$\begin{array}{l}\text { Variabel } \\
\text { Output }\end{array}$} & \multirow{3}{*}{ Harga } & Murah & [1-5] \\
\hline & & Sedang & [4-9] \\
\hline & & Mahal & [8-13] \\
\hline
\end{tabular}

\section{Analisa Metode Fuzzy Tsukomoto}

Tahap mendefinisikan karakteristik model adalah menentukan himpunan fuzzy dan mendefinisikan beberapa fuzzy yang digunakan pada sistem ini. Sistem menentukan harga coating mobil di PT Prime Coating Medan ini dibangun berdasarkan kriteria penilaian variabel. Variabel tersebut terdiri dari 2 variabel input yaitu ukuran mobil dan jumlah layer dan satu variable output yaitu harga coating mobil.

Langkah-langkah menentukan harga coating mobil dengan Metode Fuzzy Tsukomoto sebagai berikut:

a. Fuzzyfikasi

Fuzzyfikasi bertujuan untuk mengubah data masukan tegas menjadi fuzzy. Pada penelitian ini digunakan 3 variabel, yang dimana variabel ukuran mobil dan jumlah layer adalah variabel input, dan harga coating adalah variabel outpu.

1. Ukuran mobil terdiri dari 3 himpunan fuzzy yaitu 
SEDANG $=[14-18]$

BESAR $\quad=[15-20]$

Fungsi keanggotaan di presentasikan pada gambar berikut;

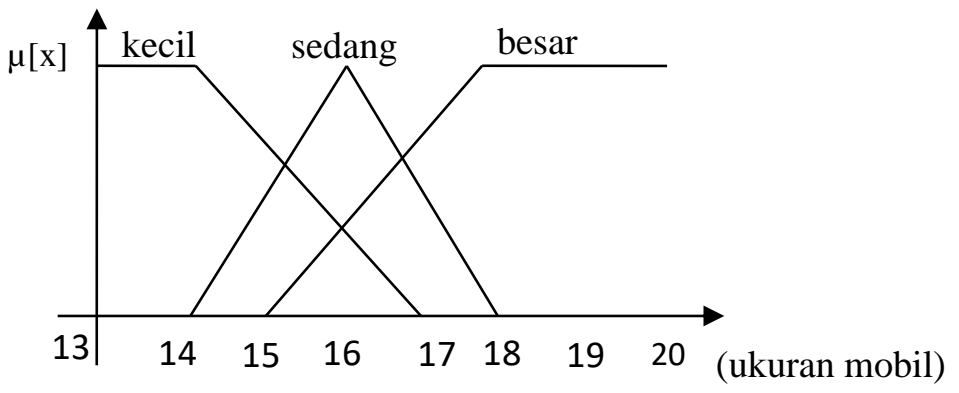

Gambar 1. Fungsi Keanggotaan pada Variabel Mobil

Fungsi keanggotaan himpunan KECIL, SEDANG, BESAR dari Variabel ukuran mobil;

$$
\begin{aligned}
& \mu \text { mobil KECIL }[\mathrm{x}] \quad=\left\{\begin{array}{cl}
1, & \mathrm{x} \leq 14 \\
\frac{17-\mathrm{x}}{17-14}, & 14 \leq \mathrm{x} \leq 17 \\
0, & \mathrm{x} \geq 17
\end{array}\right.
\end{aligned}
$$

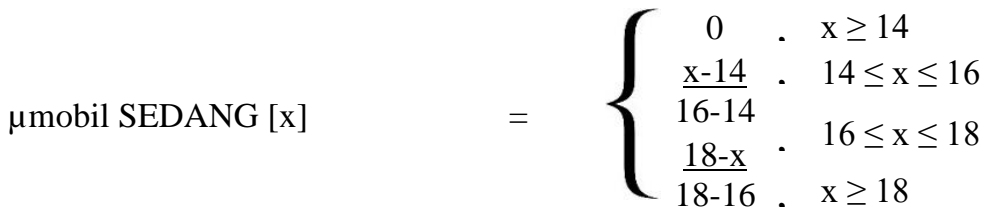

$$
\begin{aligned}
& \mu \text { mobil BESAR }[\mathrm{x}] \quad=\left\{\begin{array}{cl}
0, & \mathrm{x} \geq 15 \\
\frac{\mathrm{x}-15}{18-15} & , \quad 15 \leq \mathrm{x} \leq 18 \\
1, & \mathrm{x} \geq 18
\end{array}\right.
\end{aligned}
$$

2. Jumlah Layer terdiri dari 3 himpunan fuzzy yaitu:

$$
\begin{array}{ll}
\text { SEDIKIT } & =[1-3] \\
\text { SEDANG } & =[2-5] \\
\text { BANYAK } & =[4-7]
\end{array}
$$

Fungsi keanggotaan jumlah layer di presentasikan pada gambar berikut;

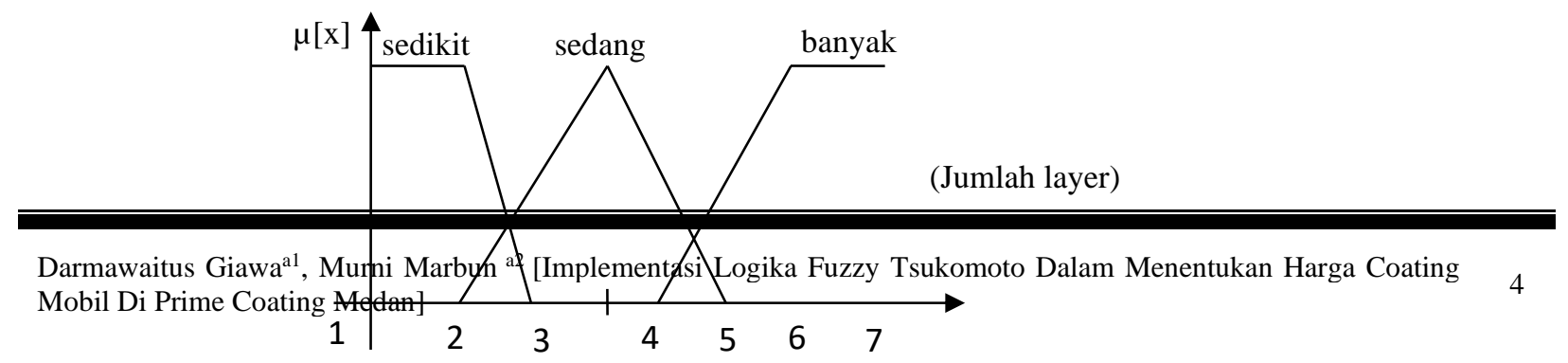


Gambar 2 Fungsi Keanggotaan pada Variabel Layer

Fungsi keanggotann Himpunan SEDIKIT, SEDANG DAN BANYAK dari variabel jumlah layer:

$\mu$ layer SEDIKIT $[\mathrm{x}]$

$=\left\{\begin{array}{cl}1, & x \leq 2 \\ \frac{3-x}{3-2}, & 2 \leq x \leq 3 \\ 0, & x \geq 3\end{array}\right.$

$=\left\{\begin{array}{cl}0, & x \geq 2 \\ \frac{\mathrm{x}-2}{3,5-2}, & 2 \leq x \leq 3,5 \\ \frac{5-\mathrm{x}}{5-3,5}, & 3,5 \leq x \leq 5 \\ 0, & x \geq 5\end{array}\right.$

$\mu$ layer BANYAK $[\mathrm{x}]$

$$
=\left\{\begin{array}{cll}
0 & \cdot & x>4 \\
\frac{x-4}{6-4} & \cdot & 4 \leq x \leq 6 \\
& x>6
\end{array}\right.
$$

3. Harga Caoting terdiri dari 3 himpunan fuzzy yaitu:
MURAH $=[1-5]$
SEDANG $=[4-9]$
MAHAL $=[8-13]$

Fungsi keanggotaan harga di presentasikan pada gambar berikut;

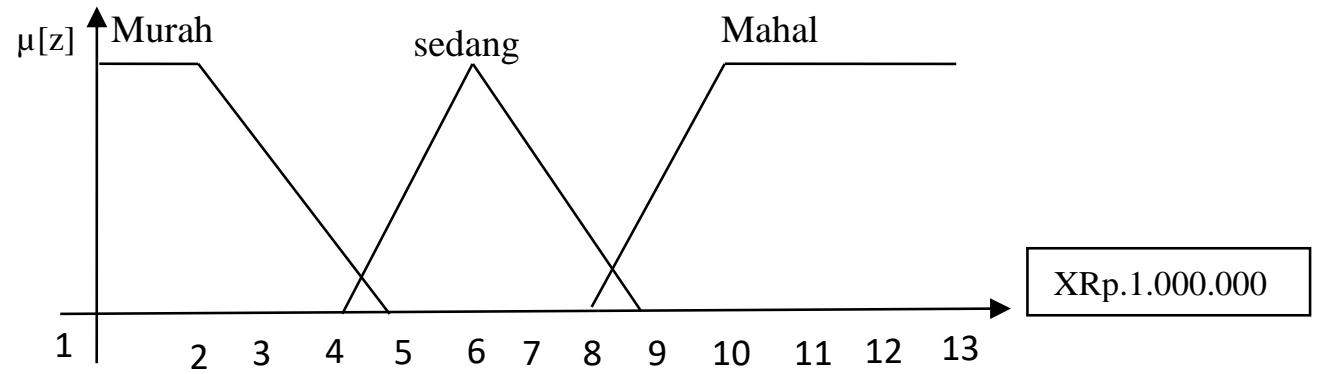

Gambar 4.6 Fungsi Keanggotaan Pada harga

$\mu$ harga MURAH [x]

$$
=\left\{\begin{array}{cll}
1 & , & x \leq 2 \\
\frac{5-x}{5-1} & , & 1 \leq x \leq 5 \\
0 & , & x \geq 5
\end{array}\right.
$$

Darmawaitus Giawa ${ }^{\mathrm{a}}$, Murni Marbun ${ }^{\mathrm{a} 2}$ Mobil Di Prime Coating Medan]

$$
\overline{\bar{m}}_{\mathrm{x}} \leq 4
$$

$\underline{x-4},{ }^{L} 4 \leq x \leq 6$

Tsukomoto Dalam Menentukan Harga Coating 
$\mu$ harga SEDANG $[\mathrm{x}] \quad=$

$\mu$ harga MAHAL [x]

$$
=\left\{\begin{array}{cll}
0, & x \leq 8 \\
\frac{\mathrm{x}-8}{10-8}, & 8 \leq x \leq 10 \\
1, & x \geq 10
\end{array}\right.
$$

Sebagai studi kasus akan di tentukan harga coating mobil Agya dengan ukuran mobil 14 dan jumlah layer 2, maka nilai fuzzy himpunan keanggotaannya adalah:

1. Nilai keanggotaan himpunan ukuran mobil KECIL, mobil SEDANG dan mobil BESAR adalah:

$\begin{array}{ll}\mu \text { mobilKECIL[14] } & =1 \\ \mu \text { mobilSEDANG[14] } & =0 \\ \mu \text { mobilBESAR[14] } & =0\end{array}$

2. Nilai keanggotaan himpunan jumlah layer SEDIKIT, layer SEDANG dan layer BANYAK adalah :

HlayerSEDIKIT[2] $\quad=1$

playerSEDANG[2] $\quad=0$

$\mu$ layerBANYAK[2] $\quad=0$

\section{b. Inferensi Fuzzy}

Untuk menentukan harga, variabel input dan variable output dibentuk inferensi fuzzy untuk mendapatkan aturan penentuan harga coating mobil. Inferensi fuzzy terdiri dari 9 aturan [R] yaitu:

[R1] IF Mobil KECIL AND Layer SEDIKIT THEN Harga MURAH

[R2] IF Mobil KECIL AND Layer SEDANG THEN Harga MURAH

[R3] IF Mobil KECIL AND Layer BANYAK THEN Harga MURAH

[R4] IF Mobil SEDANG AND Layer SEDIKIT THEN Harga MURAH

[R5] IF Mobil SEDANG AND Layer SEDANG THEN Harga SEDANG

[R6] IF Mobil SEDANG AND Layer BANYAK THEN Harga MAHAL

[R7] IF Mobil BESAR AND Layer SEDIKIT THEN Harga MAHAL

[R8] IF Mobil BESAR AND Layer SEDANG THEN Harga MAHAL

[R9] IF Mobil BESAR AND Layer BANYAK THEN Harga MAHAL

Sesudah membuat aturan (rule) seperti contoh yang di atas, maka ditentukan nilai $\alpha$ dan $\mathrm{z}$ untuk masingmasing aturan. Langkah-langkah untuk mengkonversi 9 aturan tersebut sehingga diperoleh nilai dari $\alpha$ dan $\mathrm{z}$ dari setiap aturan.

c. Analisa Logika Kabur (Fuzzy)

\section{[R1] IF Mobil KECIL AND Layer SEDIKIT THEN Harga MURAH}

Nilai keanggotaan untuk aturan fuzzy [R1] yang dinotasikan dengan $\alpha 1$ diperoleh dengan rumus sebagai berikut:

$$
\begin{aligned}
\alpha 1 & =\mu \text { mobilKECIL } \cap \mu \text { layerSEDIKIT } \\
& =\min \mu \text { mobil KECIL [14], } \mu \text { layerSEDIKIT [2] } \\
& =\min (1,1) \\
& =1
\end{aligned}
$$

Menurut fungsi keanggotaan himpunan harga MURAH dalam aturan fuzzy [R1] pada persamaan di atas maka nilai z1 adalah:

$$
\begin{aligned}
& \frac{\mathrm{Zmax}-\mathrm{Z} 1}{\mathrm{Zmax}-\mathrm{Zmin}}=\alpha 1 \\
\mathrm{Z} 1= & 10-(1 *(10-2)) \\
\mathrm{Z} 1= & 2
\end{aligned}
$$


[R2] IF Mobil KECIL AND Layer SEDANG THEN Harga MURAH

Nilai keanggotaan untuk aturan fuzzy [R2] yang dinotasikan dengan $\alpha 2$ diperoleh dengan rumus sebagai berikut:

$$
\begin{aligned}
\alpha 2 & =\mu \text { mobilKECIL } \cap \mu \text { layerSEDANG } \\
& =\min \mu \text { mobil KECIL [14], } \mu \text { layer SEDANG [2] } \\
& =\min (1,0) \\
& =0
\end{aligned}
$$

Menurut fungsi keanggotaan himpunan harga MURAH dalam aturan fuzzy [R2] pada persamaan di atas maka nilai z2 adalah:

$$
\begin{aligned}
& \frac{\mathrm{Zmax}-\mathrm{Z} 2}{\mathrm{Zmax}-\mathrm{Zmin}}=\alpha 2 \\
\mathrm{Z} 2 & =10-(0 *(10-2)) \\
\mathrm{Z} 2 & =10
\end{aligned}
$$

[R3] IF Mobil KECIL AND Layer BANYAK THEN Harga MURAH

Nilai keanggotaan untuk aturan fuzzy [R3] yang dinotasikan dengan $\alpha 3$ diperoleh dengan rumus sebagai berikut:

$$
\begin{aligned}
\alpha 3 & =\mu \text { mobilKECIL } \cap \mu \text { layerBANYAK } \\
& =\min \mu \text { mobil KECIL [14], } \mu \text { layer BANYAK [2] } \\
& =\min (1,0) \\
& =0
\end{aligned}
$$

Menurut fungsi keanggotaan himpunan harga MURAH dalam aturan fuzzy [R3] pada persamaan di atas maka nilai $\mathrm{z} 3$ adalah:

$$
\begin{aligned}
& \frac{\mathrm{Zmax}-\mathrm{Z} 3}{\mathrm{Zmax}-\mathrm{Zmin}}=\alpha 3 \\
\mathrm{Z} 3 & =10-(0 *(10-2)) \\
\mathrm{Z} 3 & =10
\end{aligned}
$$

[R4] IF Mobil SEDANG AND Layer SEDIKIT THEN Harga MURAH

Nilai keanggotaan untuk aturan fuzzy [R4] yang dinotasikan dengan $\alpha 4$ diperoleh dengan rumus sebagai berikut:

$$
\begin{aligned}
\alpha 4 & =\mu \text { mobilSEDANG } \cap \mu \text { layerSEDIKIT } \\
& =\min \mu \text { mobil SEDANG [14], } \mu \text { laye rSEDIKIT [2] } \\
& =\min (0,1) \\
& =0
\end{aligned}
$$

Menurut fungsi keanggotaan himpunan harga MURAH dalam aturan fuzzy [R4] pada persamaan di atas maka nilai $\mathrm{z} 4$ adalah:

$$
\begin{aligned}
& \frac{\mathrm{Zmax}-\mathrm{Z} 4}{\mathrm{Zmax}-\mathrm{Zmin}}=\alpha 4 \\
\mathrm{Z} 4 & =10-(0 *(10-2)) \\
\mathrm{Z} 4 & =10
\end{aligned}
$$

[R5] IF Mobil SEDANG AND Layer SEDANG THEN Harga SEDANG

Nilai keanggotaan untuk aturan fuzzy [R5] yang dinotasikan dengan $\alpha 5$ diperoleh dengan rumus sebagai berikut:

$$
\begin{aligned}
\alpha 5 & =\mu \text { mobilSEDANG } \cap \mu \text { layerSEDANG } \\
& =\min \mu \text { mobil SEDANG [14], } \mu \text { layer SEDANG [2] } \\
& =\min (0,0) \\
& =0
\end{aligned}
$$

Karena Harga SEDANG maka z5 = zTetap. Z5 adalah nilai z untuk aturan fuzzy [R5].

[R6] IF Mobil SEDANG AND Layer BANYAK THEN Harga MAHAL

Nilai keanggotaan untuk aturan fuzzy [R6] yang dinotasikan dengan $\alpha 6$ diperoleh dengan rumus sebagai berikut:

$$
\begin{aligned}
\alpha 6 & =\mu \text { mobilSEDANG } \cap \mu \text { layerBANYAK } \\
& =\min \mu \text { mobil SEDANG [14], } \mu \text { layer BANYAK [2] } \\
& =\min (0,0) \\
& =0
\end{aligned}
$$


Menurut fungsi keanggotaan himpunan harga MAHAL dalam aturan fuzzy [R6] pada persamaan di atas maka nilai z6 adalah:

$$
\begin{aligned}
& \frac{\mathrm{Z} 6-\mathrm{Zmin}}{\mathrm{Zmax}-\mathrm{Zmin}}=\alpha 6 \\
\mathrm{Z} 6 & =2+(0 *(10-2)) \\
\mathrm{Z} 6 & =2
\end{aligned}
$$

[R7] IF Mobil BESAR AND Layer SEDIKIT THEN Harga MAHAL

Nilai keanggotaan untuk aturan fuzzy [R7] yang dinotasikan dengan $\alpha 7$ diperoleh dengan rumus sebagai berikut:

$$
\begin{aligned}
\alpha 7 & =\mu \text { mobilBESAR } \cap \mu \text { layerSEDIKIT } \\
& =\min \mu \text { mobil BESAR [14], } \mu \text { layer SEDIKIT [2] } \\
& =\min (0,1) \\
& =0
\end{aligned}
$$

Menurut fungsi keanggotaan himpunan harga MAHAL dalam aturan fuzzy [R7] pada persamaan di atas maka nilai z7 adalah:

$$
\begin{aligned}
& \frac{\mathrm{Z} 7-\mathrm{Zmin}}{\mathrm{Zmax}-\mathrm{Zmin}}=\alpha 7 \\
\mathrm{Z7} & =2+(0 *(10-2)) \\
\mathrm{Z} 7 & =2
\end{aligned}
$$

[R8] IF Mobil BESAR AND Layer SEDANG THEN Harga MAHAL

Nilai keanggotaan untuk aturan fuzzy [R8] yang dinotasikan dengan $\alpha 8$ diperoleh dengan rumus sebagai berikut:

$$
\begin{aligned}
\alpha 8 & =\mu \text { mobilBESAR } \cap \mu \text { layerSEDANG } \\
& =\min \mu \text { mobil BESAR [14], } \mu \text { layer SEDANG [2] } \\
& =\min (0,0) \\
& =0
\end{aligned}
$$

Menurut fungsi keanggotaan himpunan harga MAHAL dalam aturan fuzzy [R8] pada persamaan di atas maka nilai z8 adalah:

$$
\begin{aligned}
& \frac{\mathrm{Z} 8-\mathrm{Zmin}}{\mathrm{Zmax}-\mathrm{Zmin}}=\alpha 8 \\
\mathrm{Z} 8 & =2+(0 *(10-2)) \\
\mathrm{Z} 8 & =2
\end{aligned}
$$

[R9] IF Mobil BESAR AND Layer BANYAK THEN Harga MAHAL

Nilai keanggotaan untuk aturan fuzzy [R9] yang dinotasikan dengan $\alpha 9$ diperoleh dengan rumus sebagai berikut:

$$
\begin{aligned}
\alpha 9 & =\mu \text { mobilBESAR } \cap \mu \text { layerBANYAK } \\
& =\min \mu \text { mobil BESAR [15], } \mu \text { layer BANYAK [3] } \\
& =\min (0,0) \\
& =0
\end{aligned}
$$

Menurut fungsi keanggotaan himpunan harga MAHAL dalam aturan fuzzy [R9] pada persamaan di atas maka nilai z9 adalah:

$$
\begin{aligned}
& \frac{\mathrm{Z} 9-\mathrm{Zmin}}{\mathrm{Zmax}-\mathrm{Zmin}}=\alpha 9 \\
\mathrm{Z} 9 & =2+(0 *(10-2)) \\
\mathrm{Z} 9 & =2
\end{aligned}
$$

d. Menentukan Output Crips (Deffuzzyfikasi)

Pada metode fuzzy Tsukomoto, untuk menentukan output crips digunakan defuzifikasi rata-rata terpusat, yaitu.

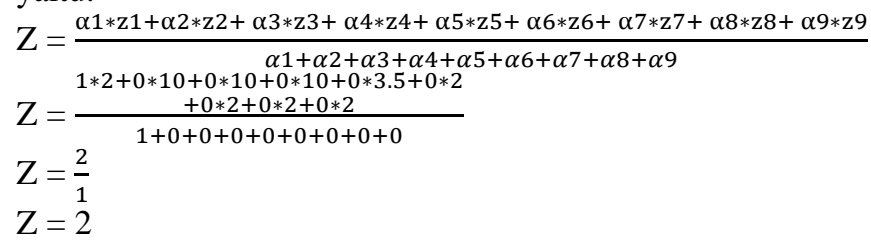

Adapun hasil perhitungan dengan fuzzy tsukamoto dapat dilihat pada tabel berikut: 
Tabel 3. Hasil Perhitungan

\begin{tabular}{cccc}
\hline No & Ukuran Mobil & Jumlah Layer & Hasil Z \\
\hline 1 & 14 & 2 & 2 \\
\hline
\end{tabular}

Berdasarkan hasil perhitungan dengan metode fuzzy Tsukamoto, maka harga coating mobil Agya dengan ukuran mobil 14 dan jumlah layer 2 adalah Rp 2.000.000. Harga coating tersebut masuk dalam kategori kecil.

\section{Mobil Sedang}

Adapun hasil perhitungan dengan fuzzy tsukamoto dapat dilihat pada table berikut ini :

Tabel 4. Hasil Perhitungan

\begin{tabular}{cccc}
\hline No & Ukuran Mobil & Jumlah Layer & Hasil Z \\
\hline 1 & 15 & 3 & 4.75 \\
\hline
\end{tabular}

Berdasarkan hasil perhitungan dengan metode fuzzy Tsukamoto, maka harga coating mobil Expander dengan ukuran mobil 15 dan jumlah layer 3 adalah Rp 4.750.000. Harga tersebut masuk dalam kategori sedang.

\section{Mobil Besar}

Adapun hasil perhitunganuntuk mobil besar dengan fuzzy tsukamoto dapat dilihat pada tabel ini:

Tabel 5. Hasil Perhitungan

\begin{tabular}{cccc}
\hline No & Ukuran Mobil & Jumlah Layer & Hasil Z \\
& & & \\
\hline 1 & 19 & 7 & 10 \\
\hline
\end{tabular}

Berdasarkan hasil perhitungan dengan metode fuzzy Tsukamoto, maka harga coating mobil Fajero dengan ukuran mobil 19 dan jumlah layer 7 adalah Rp 10.000.000. Harga tersebut masuk dalam kategori besar.

\section{IV.Kesimpulan}

Dalam penelitian Implementasi Logika Fuzzy Tsukamoto dalam Menentukan Harga Coating Mobil di Prime Coating Medan, maka didapatkan beberapa kesimpulan yaitu:

1. Penerapan logika fuzzy Tsukamoto untuk menentukan harga coating mobil dimulai dengan melakukan proses fuzzyfikasi data variable input ukurun velg dan jumlah layer dan data variable output harga coating mobil. Proses fuzzyfikasi tersebut mendapatkan nilai keanggotaan himpunan fuzzy dari setiap variable yang kemudian dianalisis dengan sembilan rule pada proses inferensi fuzzy. Nilai akhir dari hasil inferensi fuzzy diubah kebentuk nilai crips dengan proses defuzzyfikasi. Hasil defuzzyfikasi adalah nilai crisp yang menunjukkan harga coating mobil berdasarkan ukuran velg dan jumlah layer mobil.

2. Aplikasi sistem penentuan harga coating mobil di Prime Coating Mobil di desain menggunakan UML (Unified Modeling Language) yang terdiri dari usecase Diagram, Activity Diagram, Sequence Diagram, dan Class Diagram. Sistem ini dibangun menggunakan bahasa pemograman PHP dengan database PHP MySql. Implementasi sistem terdiri dari form login, form menu utama, form menu mobil, form menu proses dan form тепи laporan. Hasil implementasi dari sistem yang dibangun dapat menunjukkan harga coating mobil dan mencetak hasil perhitungan harga yang digunakan sebagai laporan. 


\section{Daftar Pustaka}

[1] V. Secapramana, "Model Dalam Strategi Penetapan Harga," Unitas, 2010.

[2] A. A. Caraka, H. Haryanto, D. P. Kusumaningrum, and S. Astuti, "Logika Fuzzy Menggunakan Metode Tsukamoto," Techno.COM, 2015.

[3] M. Dandi, K. Fernando, and T. Hidayat, "ANALISIS PREDIKSI TINGKAT KELULUSAN MAHASISWA UNIVERSITAS WIRALODRA INDRAMAYU MENGGUNAKAN METODE FUZZY TSUKAMOTO," TEKNOKOM, 2020.

[4] M. D. Irawan and H. Herviana, "IMPLEMENTASI LOGIKA FUZZY DALAM MENENTUKAN JURUSAN BAGI SISWA BARU SEKOLAH MENENGAH KEJURUAN (SMK) NEGERI 1 AIR PUTIH," J. Teknol. Inf., 2019.

[5] A. Sa'dan, H. Haryanto, S. Astuti, and Y. Rahayu, “Agen Cerdas Berbasis Fuzzy Tsukamoto pada Sistem Prediksi Banjir," Eksplora Inform., 2019.

[6] A. A. Caraka, H. Haryanto, D. P. Kusumaningrum, S. Astuti, F. I. Komputer, and U. D. Nuswantoro, "Logika Fuzzy Menggunakan Metode Tsukamoto Untuk Prediksi Perilaku Konsumen Di Toko Bangunan," Techno.COM, 2015.

[7] N. Puspitasari, A. Tejawati, and F. Prakoso, "Estimasi Stok Penerimaan Bahan Bakar Minyak Menggunakan Metode Fuzzy Tsukamoto,” JRST (Jurnal Ris. Sains dan Teknol., 2019.

[8] S. Widaningsih, "Analisis Perbandingan Metode Fuzzy Tsukamoto, Mamdani dan Sugeno dalam Pengambilan Keputusan Penentuan Jumlah Distribusi Raskin di Bulog Sub. Divisi Regional (Divre) Cianjur," Infoman's, 2017.

[9] A. I. Falatehan, N. Hidayat, and K. C. Brata, "Sistem Pakar Diagnosis Penyakit Hati Menggunakan Metode Fuzzy Tsukamoto Berbasis Android," J. Pengemb. Teknol. Inf. dan Ilmu Komput. Univ. Brawijaya, 2018.

[10] D. A. Silitonga, M. Anjelita, and A. P. Windarto, "Fuzzy Inference System Pada Prediksi Pembelian Bahan Bakar Pertamax Pada SPBU di Kota Pematangsiantar,” Syntax J. Inform., 2019. 